\title{
A história recente nos livros didáticos: a ditadura militar e a questão da anistia no Brasil ${ }^{1}$
}

\author{
Carla Simone Rodeghero* \\ Vanderlei Machado**
}

Resumo: $\mathrm{O}$ presente artigo discute maneiras de inserir a História recente do Brasil nas aulas do Ensino Médio. A partir das discussões atuais sobre a necessidade de uma nova interpretação da Lei da Anistia de 1979, o texto volta à década de 1970 para recuperar o processo de luta em prol da anistia e os limites da lei aprovada, procurando mostrar a complexidade dessa problemática e a sua fecundidade para refletir sobre o presente e o passado brasileiros. Investiga o tratamento que tem sido dado ao tema nos livros didáticos apresentados pelo Catálogo Nacional do Livro didático de 2008. Sugere, ao final, caminhos para trabalhar a anistia em sala de aula.

Palavras-chave: História do tempo presente, Livros didáticos, Lei da Anistia, Ensino Médio.

Abstract: This article discusses ways of incorporate Brazil's recent history at classes in high school. Due to current discussions on the need for a new interpretation of the Lei da Anistia (Amnesty Law) from 1979, the text gets back to the 1970s in order to recover the process of fight for amnesty and the limits of the approved law, trying to show the complexity of this issue

1 Agradecemos as contribuições de Alessandro Güntzel, bolsista CNPq/UFRGS.

* Doutora em História e professora do Programa de Pós-Graduação em História da Universidade Federal do Rio Grande do Sul (UFRGS). E-mail: carlasr@cpovo.net

** Doutor em História e professor do Colégio de Aplicação da Universidade Federal do Rio Grande do Sul (UFRGS). E-mail: vandermachado@hotmail.com 
and the fertility that generates a reflection about Brazil's present and past. It investigates the approach that has been given to this subject in High School textbooks provided by the National Catalogue of Textbooks 2008. By the end, it suggests ways to work the Lei da Anistia (Amnesty Law) in the classroom.

Keywords: History of the present time, Textbooks, Lei da Anistia, High School.

A Lei da Anistia, objeto de luta organizada desde 1975, proposta mais tarde pelo governo Figueiredo e aprovada pelo Congresso Nacional em 1979, é um caso instigante para refletir sobre a escrita da história do tempo presente e sobre o seu ensino escolar. Tal lei tem sido, recentemente, alvo de discussão e de polêmica, o que revela que o problema ao qual ela se refere ainda é bastante atual e está longe de ser solucionado. $\mathrm{O}$ presente artigo discute como a proximidade desse tema, que diz respeito ao passado e ao legado da ditadura civil-militar brasileira, pode ser abordado de forma criativa, tanto para conhecer aquele passado, quanto para discutir questôes bem atuais sobre direitos humanos e luta por justiça. A proposta será desenvolvida em dois momentos: no primeiro, serão feitos alguns comentários sobre a Lei da Anistia e sobre o debate atual em torno dela. A seguir, será explorado um conjunto de livros didáticos, buscando o tratamento dado por eles ao tema. Nas considerações finais, apresentaremos sugestões para a abordagem da anistia nas aulas de história do Ensino Médio.

\section{O golpe de 1964, a Lei da Anistia e os debates atuais}

A partir do golpe de 1964, o Brasil viveu um processo ora mais violento, ora mais disfarçado - de punição aos cidadãos considerados perigosos para o novo regime. As medidas repressivas levadas adiante pelos governos militares, tendo por base atos 
institucionais, atos complementares, reformas institucionais, legislação secreta, leis em vigor, novos órgãos e outros reformados, etc., produziram um grande número de brasileiro(a)s excluídos da condição de cidadãos e até daquela de seres humanos. Quando, em 1975, surgiu o primeiro movimento organizado em prol de uma anistia, diferentes categorias de punidos estavam à espera de uma medida que viesse restituir os seus direitos de cidadania. Entre eles havia políticos, parlamentares e membros do executivo que tinham tido seus mandatos cassados e seus direitos políticos suspensos. Muitos deles foram forçados a se retirar do país e a viver no exterior como exilados. Havia funcionários públicos civis ou militares que tinham sido expurgados do serviço público. O mesmo tinha acontecido com trabalhadores da iniciativa privada. Esse era, também, o caso dos presos políticos, condenados por ações variadas de oposição à ditadura (desde sequestros até distribuição de panfletos); de condenados pela Justiça Militar que fugiram do país para evitar a prisão; de estudantes expulsos das escolas ou das universidades por terem feito política no movimento estudantil. Havia, ainda, pessoas cujos familiares tinham sido mortos pela repressão ou desaparecidos por ela. Milhares de cidadãos brasileiros, por se colocarem contra o regime, tinham sido entre 1964 e 1975, cassados, expurgados, exilados, presos, expulsos, desaparecidos, mortos. Muitos outros passariam pelas mesmas situações até, pelo menos, agosto de 1979 (MARTINS, 1978, p. 142-155).

Em 1973, o general Ernesto Geisel foi eleito à Presidência da República, pelo Colégio Eleitoral. Em sua posse, no início de 1974, apresentou um programa de distensão: propunha afrouxar o regime, dialogar com parte da oposição, com o propósito de buscar uma legitimidade que a ditadura vinha perdendo, após a forte repressão que se seguiu ao AI-5 e no momento em que o "milagre econômico" começava a revelar problemas (MOREIRA ALVES, 2005). Nesse clima, grupos de mulheres, em diversas cidades brasileiras, deram vida ao Movimento Feminino pela Anistia, o MFPA. A entidade, através de seus núcleos, tentava 
pressionar as autoridades, entre elas o presidente da República, para a concessão da anistia. A medida era vista como uma oportunidade para pacificar o país, visto como uma família dilacerada pelos conflitos políticos. Quando a bandeira da anistia foi levantada, poucas eram as vozes dissidentes que podiam ser ouvidas pelo país. O clima ainda era de muita insegurança (RODEGHERO, 2009, p. 131-139). Apesar do propósito de afrouxamento de Geisel, continuavam intocados todos os órgãos repressivos e a legislação que lhes dava suporte. Em 1977, começou a haver alguma movimentação estudantil. Entidades secundaristas e acadêmicas com posição oposicionista, ligadas a grupos de esquerda clandestinos, começaram a pressionar os limites impostos pelo regime e, aos poucos, passaram a fazer assembleias e manifestaçôes fora das universidades, tomando as ruas (ARAÚJO, 2007). No ano de 1978, aconteceram as primeiras greves dos metalúrgicos, no ABC paulista. Aos poucos, diferentes protagonistas (sindicatos de diversas categorias de trabalhadores, igrejas, grupos feministas, movimento negros, ecologistas, moradores da periferia, etc.) passaram a apostar no "trabalho de massa", na conscientização de operários, estudantes, donas de casa, agricultores sem terra, professores, consumidores, etc. Queriam mostrar que a união podia levar à conquista das demandas coletivas. Começava-se a falar em direitos humanos. A luta específica contra a ditadura se somava - muitas vezes com dificuldade - a outras que começavam a se organizar, como a luta contra a carestia e o custo de vida, contra a discriminação racial e sexual, contra a concentração da terra, contra o arrocho salarial, etc. (GRECO, 2003, cap. 5).

Nesse quadro, o movimento em prol de uma Lei de Anistia ganhou força e se transformou. Surgiram, no início de 1978, os primeiros Comitês Brasileiros pela Anistia (CBAs), que congregavam, em seus núcleos espalhados pelo Brasil e no exterior, pessoas e entidades (como os núcleos do MFPA) empenhadas na luta pela anistia e também nas demais lutas em curso. Ao longo de 1978, com o início da realização de encontros nacionais dos movimentos pela anistia, surgiu a bandeira da "anistia ampla, geral e 
irrestrita”, que se tornou a marca dessa luta. Com esses adjetivos, o movimento queria dizer que deviam ser anistiados todos os atos considerados crimes de oposição à ditadura; que todos os envolvidos deveriam ser atingidos pela lei; e que não deveria haver nenhum tipo de restrição ao gozo deste direito (GRECO, 2003, p. 90). É importante lembrar que, segundo a Constituição em vigor, cabia apenas ao Presidente da República a prerrogativa de enviar um projeto de lei de anistia ao Congresso. Assim, mesmo que os movimentos sociais buscassem aliados no seio do MDB, partido de oposição, este não poderia apresentar um projeto de anistia. Apenas o presidente da República! Geisel negou, durante todo o seu mandato, essa possibilidade. Ele queria que a distensão fosse "lenta, gradual e segura". Uma anistia lhe parecia medida perigosa. Quando Figueiredo assumiu, no início de 1979, a pressão dos movimentos sociais, de entidades de peso da sociedade civil e especificamente do movimento pela anistia, fizeram com que o general admitisse o envio de um projeto de anistia. Este, porém, previa que a medida deveria atingir tanto os opositores do regime quanto os que participaram da repressão, como agentes do Estado. A ideia de uma anistia recíproca foi combatida pelos CBAs, que viam a medida como um instrumento para romper com a ditadura e não como forma de salvaguardar os sustentáculos dela. O Congresso Nacional que votou a lei tinha maioria da Arena, partido do governo. Entre os instrumentos adotados pelos militares para garantir a aprovação de seus projetos estava a figura do "Senador biônico", eleito indiretamente. Assim, no Congresso, foi aprovada a proposta governamental que significava uma lei restrita (não atingia todos os crimes e não garantia imediato gozo do direito) e recíproca (que era entendida como beneficiando tanto os opositores quanto os agentes da ditadura)(Ver Anexo I). Isso, no entanto, não foi visto como derrota completa pelo(a) $s$ militantes da anistia. Elas e eles sentiram que sua luta tinha sido fundamental para a volta da maioria dos exilados e para a libertação de quase todos os presos políticos. Por outro lado, muitas demandas ficaram sem resposta, como as que se referiam à 
reintegração dos funcionários públicos civis, e especialmente dos militares, e como aquelas que estavam relacionadas aos casos de mortes e de desaparecimentos.

A anistia, então, apesar de ter sido um instrumento usado pelo governo Figueiredo para uma saída tranqüila dos militares do poder, foi também objeto e resultado de uma intensa campanha de parcelas da sociedade que marcou a segunda metade da década de 1970 e que funcionou como um laboratório de fazer política, quando estava em jogo a reconquista das liberdades democráticas e o reconhecimento dos direitos humanos.

Por que, depois de 30 anos, o tema volta ao debate político brasileiro?

Depois de 1979, as pressões dos interessados (ainda não devidamente atingidos pela anistia) e o envolvimento de alguns parlamentares e de entidades de direitos humanos fizeram com que no Executivo e no Legislativo brasileiro fossem dados novos passos para sanar as lacunas da lei de 1979 (MEZAROBBA, 2007). Houve, por exemplo, o reconhecimento da responsabilidade do Estado nos casos de mortes e desaparecimentos e está em curso o pagamento de indenizações trabalhistas aos perseguidos políticos. Nos últimos anos, a Comissão da Anistia, do Ministério da Justiça, tem investido num trabalho com a memória dos atingidos pela ditadura, tentando difundir uma cultura de respeito aos direitos humanos (SILVA JR., 2009, p. 47-92).

Muitas outras lacunas ou feridas, no entanto, continuam abertas. A principal delas diz respeito à identificação e à responsabilização criminal dos agentes do Estado que cometeram atos de tortura, que sequestraram e assassinaram opositores do regime. A falta de avanços nessa direção é resultado, entre outras coisas, da interpretação que o Judiciário brasileiro vem dando à Lei da Anistia. Ela é entendida como recíproca. Estando perdoados os crimes cometidos por integrantes de ambos os lados da "guerra" durante a ditadura, não há formas de responsabilizar os agentes do Estado. 
Essa interpretação, no entanto, vem sendo questionada ultimamente com base em argumentos como os dois que seguem. O primeiro é de que a tortura e o sequestro são crimes contra a humanidade. O Brasil já assinou convenções internacionais que defendem essa posição e, por isso, tem compromisso em fazer justiça às vítimas desses crimes. $\mathrm{O}$ segundo argumento é de que a expressão "crimes conexos" que consta da lei, não poderia ser entendida como significando reciprocidade. A repressão é ação de agentes do Estado e não uma ação conecta aos crimes cometidos por motivos políticos (BICUDO, 2009).

Essas discussões ganharam força a partir de julho de 2008, quando o Ministério da Justiça promoveu uma audiência pública para discutir "as possibilidades jurídicas de realizar julgamentos por violações de direitos humanos” (SILVA Jr., 2009, p. 91). Um pouco depois, a OAB apresentou, para análise do Supremo Tribunal Federal, uma Arguição de Descumprimento de Preceito Fundamental da Constituição (a ADPF 153), no sentido de validar ou não a interpretação - corrente e hegemônica - de que a referida lei havia anistiado os dois lados envolvidos nos confrontos que marcaram a ditadura. $\mathrm{A} \mathrm{OAB}$ defendeu, nessa ação, que a Anistia de 1979 era incompatível com a Constituição de 1988. Pela Carta Magna, o crime de tortura é considerado inafiançável e insuscetível de graça e de anistia. Por conta disso, a justiça brasileira deveria fazer uma nova interpretação da lei, especialmente no que se refere à anistia aos "crimes conexos", entendidos como aqueles cometidos pelos órgãos da repressão. Em abril de 2010, a posição do Supremo foi de que não cabia ao Judiciário decidir sobre o caso, já que a Lei de 1979 tinha sido fruto de discussão e de votação no Congresso Nacional. ${ }^{2}$ Ela significaria o resultado de um amplo acordo com o objetivo de encaminhar a volta à democracia. Nos votos dos ministros também esteve

2 Vídeos com os votos podem ser assistidos em: http://hannaharendt.wordpress. com/2010/04/30/votos-stf-adpf153-lei-de-anistia. 
presente o argumento de que a anistia tinha sido recíproca. ${ }^{3}$ Tais argumentos, em nossa opinião, poderiam ser desmontados com uma simples leitura dos jornais brasileiros na época da votação da lei. Todos eles caem por terra se comparados com as pesquisas acadêmicas sobre o tema e com as memórias dos que participaram dessa luta.

$\mathrm{O}$ resultado do julgamento da $\mathrm{ADPF}$, no entanto, não foi novidade. Meses antes, outro episódio havia demonstrado o quanto seria/ o quanto é difícil mexer na interpretação da lei da Anistia. A Presidência da República, através da Secretaria Especial dos Direitos Humanos, lançou, em janeiro de 2010, o Plano Nacional dos Direitos Humanos. ${ }^{4}$

Uma das suas metas era a instalação de uma Comissão Nacional de Verdade, que seria responsável pela averiguação de responsabilidades daqueles agentes do Estado que, durante a ditadura, cometeram crimes como assassinatos, sequestros, tortura, considerados crimes contra a humanidade. Não demoraram a surgir reações, parte das quais baseava sua condenação a tal meta numa interpretação de que a Lei da Anistia teria perdoado tanto os crimes cometidos por opositores do regime, quanto aqueles dos que o defendiam. Tendo sido recíproca a anistia, os crimes do período não poderiam ser alvos de posterior julgamento. Por isso não faria sentido criar uma Comissão de Verdade.

3 Alguns sites na Internet onde a votação do STF foi analisada:

- STF rejeita revisão da Lei da Anistia. Artigo publicado pela ABI. Disponível em www. abi.org.br/primeirapagina.asp? id =3545. Acesso em 15 maio 2010.

- Comissão de Direitos Humanos da AMB lamenta decisão do STF sobre Lei de Anistia. Artigo da Associação de Magistrados Brasileiros. Disponível em http://www.amb. com.br/?secao $=$ mostranoticia\&mat_id $=20620 \&$. Acesso em 15 maio 2010.

- Decisão histórica no STF. Artigo publicado no blog de Luciana Genro. Disponível em www.lucianagenro.com.br/2010/04/decisao-historica-no-stf/. Acesso em 16 maio 2010.

- Campanha pede que STF negue anistia aos torturadores da Ditadura. Artigo do Movimento Nacional de Direitos Humanos. Disponível em http://www.mndh.org.br/index. php?option $=$ com_content\&task $=$ view\&id $=1949 \&$ Itemid $=56$. Acesso em 16 maio 2010.

4 Para ver a íntegra do Plano e o debate em torno dele, ver http://www2.fpa.org.br/ programa-nacional-de-direitos-humanos-3-e-falsas-polemicas. 
Esses argumentos fazem parte daquilo que se poderia chamar da "guerra de memória" em torno da herança da ditadura civil-militar no Brasil (MARTINS FILHO, 2003, p. 178-201). Trata-se de mais uma batalha na definição do significado da experiência pela qual o país passou entre 1964 e 1985 e sobre como lidar, num tempo que se diz democrático, com a herança daquele passado. A questão da anistia, como se vê, tem ocupado algum espaço no debate político nacional. Em praticamente todas as manifestações sobre a questão da anistia (no Congresso Nacional, na imprensa, no judiciário, em diferentes setores do executivo federal), estão presentes um relato do que teria acontecido no passado (na ditadura como um todo e na aprovação da Lei da Anistia) e uma avaliação da contribuição ou dos limites de tal lei para a transição rumo à democracia. Não se tem dado a merecida ênfase na anistia como processo de luta social. Essa mesma lógica marca a abordagem dos livros didáticos sobre ao tema?

\section{A anistia nos livros didáticos de História}

No presente estudo, analisamos um conjunto de onze livros didáticos de História, de um total de vinte manuais, indicados no Catálogo do Programa Nacional do Livro para o Ensino Médio. Essas obras foram distribuídas às escolas públicas de todo o Brasil, em 2008. Dos onze livros selecionados, dez tratavam da anistia. $\mathrm{O}$ fato de a maioria dos livros didáticos fazerem menção ao tema em estudo pode ser um indicativo da importância de se abordar esse fato da história recente do Brasil. Buscou-se conhecer e comparar a forma como os livros abordavam o tema: se enfatizavam o projeto governamental ou o aspecto da luta dos movimentos sociais; se mencionavam os protagonistas coletivos e individuais; se destacavam o pioneirismo e o protagonismo feminino; de que forma associavam os movimentos pela anistia aos outros movimentos em curso no final da década de 1970; e se deixavam alguma indicação sobre a inconclusão desse processo. 
Ao fazermos tais questões aos livros didáticos, tínhamos consciência de que não existe um processo automático ou veloz de apropriação para os manuais escolares das pesquisas feitas na academia. Assim, mesmo que para o ano de 2005 (no qual a maioria dos livros foi publicada), já existissem estudos sobre o tema, isso não significa que já estivessem à disposição para os professores do ensino básico e, mesmo, que já estivessem sendo usados nos cursos de licenciatura em História. Com essas ressalvas, queremos conhecer e compreender como o tema da anistia tem sido abordado nesses manuais escolares que, sabemos, não são a única fonte de informação para os alunos e nem são a única ferramenta disponível para os professores prepararem suas aulas.

Comecemos atentando para os protagonistas mencionados. No livro de Braick e Mota, História das cavernas ao terceiro milênio, algumas entidades são destacadas por "promoveram debates com a participação expressiva da sociedade", na segunda metade da década de 1970: "entidades, como a Ordem dos Advogados do Brasil (OAB), a Associação Brasileira para o Progresso da Ciência [ABPC], o Comitê Brasileiro pela Anistia [CBA], a Associação Brasileira de Imprensa [ABI], as Comunidades Eclesiais de Base [CEBs] e a UNE [União Nacional de Estudantes]”. (2005, p. 166). Em outro momento, as autoras lembram que "uma das bandeiras da luta que naqueles anos ganhou amplitude social e política nacional foi a da anistia aos presos, cassados, banidos, exilados e perseguidores políticos. Em 1975 foi criado o Movimento Feminino pela Anistia, com a participação de mães e familiares de 'desaparecidos', presos políticos e exilados" (2005, p. 166).

Vê-se que as autoras mencionam entidades como a OAB, a $\mathrm{ABPC}$, a $\mathrm{ABI}$, que reuniam profissionais liberais ou do universo acadêmico. Essas organizações tinham uma postura crítica à ditadura. Ainda assim, segundo Maria Helena Moreira Alves, elas eram vistas pelo governo Geisel como uma “oposição confiável”, rótulo que também se estendia ao MDB (MOREIRA ALVES, 2005). Era com elas e com o partido de oposição que o governo estava disposto a dialogar em seu projeto de distensão. Aqui, Braick e 
Mota colocam tais entidades ao lado de outras que estavam bem mais próximas da proposta de retomada do trabalho de massa, antes mencionado. Seriam, na lógica proposta por Moreira Alves, menos confiáveis para o Governo. Era o caso das Comunidades de Base ligadas à Igreja Católica e da União Nacional dos Estudantes, em vias de reconstrução. Em meio a essas entidades, é mencionado o CBA, criado no Rio de Janeiro em 1978. Braick e Mota também lembram que a partir daí "a campanha ganhou fôlego em torno da bandeira da anistia ampla, geral e irrestrita” (2005, p. 166).

Os núcleos dos CBAs que funcionavam no Brasil, congregavam, em muitos casos, representantes dessas entidades mais antigas, mas eram formados especialmente por representantes das novas organizações que surgiam no final dos anos $1970 .{ }^{5}$ Até pouco tempo atrás, a $\mathrm{OAB}$, a $\mathrm{ABI}$, a $\mathrm{CNBB}$, Conferência Nacional dos Bispos do Brasil, e o MDB eram as organizaçôes mais citadas ao se falar na luta pela redemocratização na segunda metade dos anos 1970 (KUCISNK, 1982). Os CBAs não ganhavam tanta importância. A situação mudou com estudos mais recentes, concentrados no tema da luta pela anistia (GRECO, 2003; SILVA,

5 Para se ter uma ideia da composição de um CBA, podemos observar o caso do CBA-RS. Um manifesto de 14 de agosto de 1979 marcou o Dia Nacional de Luta pela Anistia Ampla, Geral e Irrestrita. As entidades que assinaram o documento, encabeçadas pelo CBA-RS foram as seguintes: MFPA-RS, AMPLA, Conselho de Defesa dos Direitos Humanos, Centro Brasil Democrático, Grupos do Professores Atingidos da UFRGS, UNE, Adufrgs, Associação Nacional dos Médicos Residentes, Associação dos Sociólogos do Brasil, Instituto dos Arquitetos Brasileiros - RS, Federação do Magistério do Estado do Rio Grande do Sul, Associação Gaúcha dos Advogados Trabalhistas, DCE-UFRGS, Associação Gaúcha dos Sociólogos, Federação RioGrandense de Associaçóes Comunitárias e Amigos de Bairros (Fracab), Sindicato dos Empregados em Estabelecimentos Bancários de Porto Alegre, Diretório "Paulo Freire" da Unisinos, União Metropolitana de Estudantes Secundários de Porto Alegre, IEPES, Setor Jovem Metropolitano do MDB, Tendência Socialista do MDB, Convergência Socialista, Associação de Estudos e Debates do PTB, Comissão Pró-PT, Comitê de Libertação pelos Presos de Itamaracá e Centro dos Estudantes do Colégio Júlio de Castilhos. Como se vê não há menção às entidades tradicionais, como a $\mathrm{OAB}$ e a ARI (Associação Rio-Grandense de Imprensa). Fonte: Acervo do MFPA, Centro de Memória Documental da Ditadura Militar no Rio Grande do Sul, Arquivo Histórico do Rio Grande do Sul. 
2009). Na época da tramitação do projeto, no entanto, era comum que a imprensa falasse apenas nesses grandes atores, não admitindo sequer mencionar a existência de um movimento autônomo em prol da anistia. Muitas vezes, por ainda serem relativamente desconhecidos os estudos específicos sobre a anistia, os livros didáticos e mesmo os manuais universitários repetem essa lógica. Esse não foi, no entanto, o caso do trabalho de Braick e Mota.

Campos e Miranda, em A Escrita da História, apresentam um capítulo intitulado "A volta dos estudantes", que começa assim: "Pelas liberdades democráticas'; 'Em defesa do ensino público e gratuito'; 'Anistia a todos presos e exilados políticos'; 'Pelo fim da Censura'; 'Abaixo a ditadura'. Em 1977, cabeludos, barbudos e inconformados, os jovens traziam novamente suas palavras de ordem para as ruas em várias cidades do país” (2005, p. 606). Aqui, o tema da anistia aparece associado às outras bandeiras do movimento estudantil. Ao caracterizar os jovens como barbudos, o texto acaba excluindo as mulheres que, como sabemos, também integravam o movimento estudantil e que, fora dele, tinham sido pioneiras na criação do Movimento Feminino pela Anistia. No capítulo seguinte, o tema da anistia é tratado diretamente em um parágrafo. É mencionado o protagonismo do presidente Figueiredo, "concedendo a anistia e permitindo a reorganização partidária” (2005, p. 609). Os autores lembram que "os setores mais organizados da sociedade reivindicavam uma anistia ampla, geral e irrestrita” (2005, p. 609). Como se vê, é sumária e apenas implícita a menção a entidades organizadas envolvidas nesta campanha.

Gilberto Cotrim, em História Global: Brasil e geral, toca no tema da anistia, sem associá-lo a um movimento social. Divalte Figueira, no livro História, da mesma forma, trata da anistia sem descrever o movimento popular que a demandava e sem tocar na participação feminina: "Pressionado por diversos setores da sociedade, Figueiredo enviou ao Congresso Nacional um projeto de anistia política logo no começo de seu governo" (2005, p. 381). Uma rica experiência de luta fica escondida atrás da ideia 
da pressão de "diversos setores da sociedade", que não permite conhecer a existência de entidades como os núcleos do MFPA e os CBAs e também a solidariedade prestada a essa luta por outros movimentos, como o movimento estudantil e o sindical.

Lima, Carvalho e Pedro, em História do Mundo Ocidental, apresentam a anistia como uma concessão do governo Figueiredo: "Uma das primeiras medidas do governo foi a anistia política, ou seja, os exilados e os que tiveram seus direitos cassados poderiam voltar à vida política normal"(2005, p. 514). Ao falar que a anistia foi uma das primeiras medidas do governo Figueiredo, o livro passa a impressão que o presidente chegou ao poder convicto da necessidade de encaminhar tal medida. Já demonstramos acima que esse não foi o caso.

José Geraldo Vinci de Moraes, por sua vez, em História Geral e do Brasil, faz uma menção muito breve à anistia, ao relatar que "durante o governo do general Figueiredo, algumas reivindicações da sociedade foram concretizadas, ampliando a abertura política. Por exemplo, a anistia, sancionada pelo presidente em 1979”. (2005, p. 426). Pode-se chamar a atenção para o uso do substantivo "sociedade" como sujeito. Como foi apontado acima, surgiram, antes e durante o governo Figueiredo, entidades novas ou renovadas, empunhando bandeiras de volta ao Estado de direito e apostando num trabalho de massa, diferente da atuação clandestina e, às vezes violenta, que havia marcado a oposição nos anos de maior fechamento do regime. "A sociedade" como um todo pode ter sido alvo das campanhas dessas entidades, visando conscientizar um maior número de pessoas para a necessidade de lutar pela reconquista do espaço público. Houve, inclusive, intensos esforços dos movimentos pela anistia para se aproximarem de outros movimentos sociais. Mas, é preciso lembrar que mesmo sendo bem sucedida a aproximação, isso não significaria abarcar toda "a sociedade". Por isso, parece muito vago falar da anistia como fazendo parte de "algumas reivindicações da sociedade".

Ojeda, Petta e Delfini assim se referem ao nosso tema no livro História, uma abordagem integrada: "no final da década de 
1970, surgiu a campanha pela anistia dos condenados políticos" (2005, p. 317). Sabemos que a campanha começou na metade dos anos 70 e não no final do decênio. Os autores relatam, ainda, que "a campanha tornou-se bastante popular, mobilizando estudantes, trabalhadores e organizações civis, que promoviam atos públicos por todo o país" (2005, p. 317). Temos, aqui, uma ênfase na popularização da campanha, ainda que sem mencionar entidades.

Mario Schmidt, em Nova História Crítica relata que "em 1975, foi criado o MFA (Movimento Feminino Pela Anistia), que lutava para que os presos políticos fossem soltos, os exilados pudessem voltar à pátria e os cassados recebessem justiça. Em 1978, foi criado o CBA (Comitê Brasileiro pela Anistia). O Brasil inteiro repudiava a tortura e a arbitrariedade. A saudosa Elis Regina emocionava o país cantando o hino da Anistia: $\mathrm{O}$ bêbado e o equilibrista (de Aldir Blanc e João Bosco). Outros cantores populares, como Chico Buarque e Milton Nascimento, compunham músicas com críticas sutis ao regime militar" (2005, p. 760). Do texto de Schmidt pode-se destacar a menção a cinco nomes próprios: todos eles de artistas que contribuíram, sem dúvida, para a popularização do movimento. Os nomes do(a)s militantes e lideranças do MFPA e dos CBAs não chegaram aos livros didáticos. Isso pode ser explicado pela própria estrutura descentralizada, no caso dos CBAs e pela insistência com que a imprensa, o governo e os parlamentares silenciavam sobre a entidade e suas lideranças. Por outro lado, a afirmação de Schmidt de que "o Brasil inteiro repudiava a tortura e arbitrariedade" pode ser questionada. Sabe-se, hoje, que parcela importante da sociedade seguia alheia aos embates políticos que marcaram a ditadura (REIS FILHO, 2000). Por isso mesmo, o regime teve legitimidade e não entrou em colapso, como aconteceu com ditaduras de países vizinhos.

Dos oito livros analisados neste tópico, apenas dois (os de Braick e Mota e o de Schmidt) mencionaram as entidades criadas especificamente para lutar pela anistia. Uma das obras (o livro de Ojeda, Petta e Defini) mencionou a mobilização de estudantes, trabalhadores e entidades civis. Nos demais trabalhos, ou a anistia 
é reivindicação "da sociedade", de "diversos setores da sociedade" ou é concessão do governo. Percebe-se, assim, que a dimensão da anistia como objeto de luta não é a mais explorada nos livros em questão.

Quando tratam dos alvos e do alcance da anistia, os autores dos manuais analisados tendem a enfatizar duas categorias: os exilados e os cassados. Gilberto Cotrim se refere exatamente a estes dois alvos da medida, "os exilados e as pessoas que tiveram direitos políticos cassados”(2005, p. 565). Com isso, deixa de mencionar outras categorias que também necessitavam da anistia, como os presos políticos, os funcionários públicos expurgados, os parlamentares com mandatos cassados, os estudantes expulsos das escolas e universidades. Há, ainda, uma observação sobre os limites da lei: "Mas a anistia não foi irrestrita; os militares punidos na ditadura, por não se terem engajado no golpe, não puderam voltar às forças armadas” (COTRIM, 2005, p. 565). Outras restriçôes presentes na lei poderiam também ser mencionadas: os funcionários públicos civis - e não apenas os militares - teriam que passar pelo exame de Comissóes do poder executivo para retornarem aos seus postos, caso houvesse vagas e interesse do serviço público. Além de dizer que a anistia não foi irrestrita, seria possível mencionar também que ela não foi nem ampla, nem geral, como queriam os movimentos sociais: ela não atingiu nem todos os atos considerados crime, nem todos os envolvidos: só foram anistiados "crimes" punidos por fundamento nos atos institucionais e complementares. Punições resultantes da CLT, de códigos disciplinares das Forças Armadas, de decretos relacionados aos estudantes, etc., não seriam anuladas. Crimes como atentados e sequiestro, cometidos por motivos políticos, ficaram excluídos da anistia.

Lima, Carvalho e Pedro também enfatizam a volta dos exilados e a anistia aos cidadãos com direitos políticos cassados. As demais categorias atingidas pela repressão não aparecem como alvos da medida. Ojeda, Petta e Delfini, por sua vez, informam que "o movimento pretendia a aprovação de uma lei que garantisse $\mathrm{o}$ 
retorno ao Brasil das pessoas condenadas pela militância política e, também, das que tiveram os direitos políticos cassados. Sem o respaldo da lei de anistia, os condenados seriam presos assim que pisassem o solo nacional" (2005, p. 317). Temos, aqui, mais uma vez, a ênfase em duas categorias de beneficiados pela anistia: os exilados e os que tiveram direitos políticos cassados. Para mostrar como este relato é incompleto, basta lembrar um exemplo: durante quase toda a discussão parlamentar do projeto da anistia (entre o final de julho e o final de agosto de 1979), houve uma greve de fome dos presos políticos que iniciou em julho de 1979 e envolveu presos de seis estados brasileiros (GRECO, 2003, cap. 7). Um dos ganhos com a greve foi fazer que membros da Comissão Especial do Congresso que analisavam o projeto e que recebiam as emendas fossem para as prisões, inspecionar a situação dos presos políticos. Teotônio Vilela - que presidia a citada comissão - foi um deles. Por este e outros atos, Milton Nascimento e Fernando Brant o homenagearam, anos mais tarde, com a música "O menestrel das Alagoas” (Ver anexo II).

Mário Schmidt, por sua vez, associou a medida a uma demanda de três categorias de vítimas da ditadura (presos, exilados e cassados). Campos e Miranda, em seu parágrafo sobre a anistia, dizem que a reivindicação da anistia ampla, geral e irrestrita se referia aos seguintes casos: "a libertação de todos os presos políticos, a volta de todos os exilados e a restituição dos direitos políticos a todos os cassados" (2005, p. 609). Sabemos que havia outras categorias envolvidas na luta. Uma delas era a dos familiares de mortos e desaparecidos que entre 1978 e 1979 começaram a montar os primeiros dossiês de mortos e de desaparecidos (GRECO, 2003, cap. 10). Estes grupos participavam ativamente dos CBAs e dos congressos nacionais pela anistia e pediam informações sobre os familiares desaparecidos ou mortos, a responsabilização dos agentes do Estado, o esclarecimento das circunstâncias das mortes, etc.

No livro História, de Seriacopi e Seriacopi, lê-se que no ano de 1979 "ganhou força a campanha em prol da anistia dos presos 
políticos, cassados e perseguidos pela ditadura em geral. Cedendo à pressão popular, em agosto de 1979, o Congresso aprovou a lei de anistia”. (2005, p. 486) Na frase curta não se pode ter noção de que campanha foi essa e de como se deu a pressão popular. Da mesma forma, ao falar apenas do Congresso, e não do Executivo, perde-se de vista o fato de que o projeto de lei só poderia ter sido apresentado pelo Presidente da República.

No que se refere ao alcance e às limitaçóes da lei, Braick e Mota registraram que: "O presidente encaminhou para o Congresso um projeto de anistia restrita e parcial, que foi repudiado por todas as correntes políticas que lutavam pela anistia ampla, geral e irrestrita. O projeto que foi aprovado em junho de 1979 beneficiava os acusados de crimes políticos, mas não se estendia aos condenados por atentados e sequiestros políticos; atingia os cassados, mas estes continuavam inelegíveis; referia-se aos servidores públicos e militares punidos pelos Atos Institucionais e Lei de Segurança Nacional, mas subordinava sua reintegração à decisão das autoridades de cada setor; para os militares, a lei anistiava automaticamente os torturadores. Aos poucos, porém, a lei de anistia foi ampliada. Assim, muitos cassados puderam concorrer às eleições de 1982”. (2005, p. 167). Vê-se aqui um balanço bem mais completo do que o apresentado em outras das obras analisadas. Seria necessário, no entanto, rever a frase final, pois até 1982 não houve mudança na lei, como as autoras afirmam. O que ocorreu é que casos não atendidos pela lei foram resolvidos de outra forma e pessoas que não tinham sido anistiadas foram indultadas pelo presidente da República ou tiveram suas penas reduzidas pela Justiça Militar (ABREU, 2001, p. 1472).

Em Dilvate Figueira lê-se que: "aprovado o projeto em agosto de 1979, líderes políticos que estavam no exterior desde o golpe de 1964, como Leonel Brizola, Miguel Arraes, Luis Carlos Prestes, puderam voltar ao Brasil. Mas a anistia beneficiava também os torturadores da ditadura, os que tinham atuado nos porões dos órgãos da repressão e eram responsáveis por muitas mortes.” (2005 p. 381). As duas frases tocam em questões que 
são bastante complexas e por isso merecem algum comentário: ao associar a anistia à volta dos exilados - especialmente de Brizola, Arraes e Prestes - o livro didático repete um consenso que foi sendo construído pela imprensa no período próximo à votação e promulgação da lei. Se a anistia fosse apenas garantir a volta dos exilados - e daqueles da "velha guarda" - ela seria mais digerível para o regime do que se ela fosse vista com a medida que libertaria presos políticos (muitos envolvidos em "ações terroristas"); como medida que reintegraria às Forças Armadas militares nacionalistas e de esquerda, assim como funcionários públicos civis que haviam sido expurgados; como instrumento para que retornassem às universidades e escolas estudantes que haviam sido expulsos ou forçados a viver na clandestinidade, etc. Queremos dizer que a ênfase na associação entre anistia e volta destes três exilados mencionados obscurecia os outros alvos da medida e fazia com que as limitações da lei não ficassem tão claras. Como questionar as restriçốes da lei num clima de festa pela chegada dos exilados? E destes três exilados em especial?

A segunda frase de Figueira que merece exame diz respeito aos torturadores terem sido beneficiados pela anistia. Realmente foi o que aconteceu. O entendimento geral - desde que a proposta do governo veio a público - era de que a anistia seria uma medida recíproca, que atingiria os indivíduos situados em ambos os lados do confronto político. No entanto, a letra da lei não diz isso (Ver anexo I). Ela apenas se refere à anistia a "crimes conexos aos políticos". Até muito pouco tempo atrás, como mencionamos acima, o judiciário brasileiro entendeu que crimes conexos eram os cometidos pelos agentes do Estado, visando conter as ações subversivas da oposição. Isso impediu que a Justiça fosse vista pelas vítimas e pelos familiares de vítimas da ditadura, como espaço para responsabilização pelos crimes cometidos pelos "defensores da ordem". Esta visão tem sido questionada nos últimos anos por setores da sociedade civil, juristas, militantes dos direitos humanos e mesmo por setores do Executivo federal no governo Lula. 
Ojeda, Petta e Delfini também se referem a este ponto ao afirmarem que "o general Figueiredo aprovou a Lei de Anistia, concedendo perdão aos adversários do governo e aos participantes da repressão. Ficaram, então, anistiados os dois lados do conflito: os chamados guerrilheiros e os agentes militares suspeitos de prender, torturar e matar os presos políticos” (2005, p. 317).

Rezende e Didier, em Rumos da História: História Geral e do Brasil foram sucintos no tema em questão, ao afirmarem que "em 1979, foi importante a aprovação da lei da anistia, ainda que não atendesse aos propósitos das oposições, pois a anistia governamental não era nem ampla nem irrestrita, beneficiando apenas algumas vítimas do regime militar” (2005, p. 623). Para o entendimento da frase seria necessário dar resposta a questões como as que seguem: o que é uma lei de anistia? Porque foi aprovada em 1979? Quem a aprovou? O que significa dizer que ela não era nem ampla, nem irrestrita? Qual era o conjunto das vítimas da ditadura? Quais vítimas foram beneficiadas por esta lei? Além disso, ao falar apenas da aprovação da lei, o texto silencia tanto sobre a luta em prol da anistia, quando para os propósitos que o governo tinha com a lei.

No livro de Seriacopi e Seriacopi, o alcance da anistia é assim avaliado: "a medida, que permitiu o retorno ao país de exilados que se encontravam no exterior, implicou também o perdão aos crimes cometidos pelos agentes da ditadura envolvidos em torturas e assassinatos de presos políticos. Estima-se que cerca de 10 mil pessoas foram beneficiadas. Lideranças políticas como Luís Carlos Prestes, Leonel Brizola, Miguel Arraes, o educador Paulo Freire, o sociólogo Herbert de Souza, entre muitos outros que se encontravam no exílio, começaram a retornar para o Brasil, ao mesmo tempo em que presos políticos foram postos em liberdade" (2005, p. 486). Há aqui o reconhecimento dos limites da Lei (perdão aos agentes da ditadura), o destaque para os exilados que puderam voltar e para os presos que foram libertados. Prestes, Brizola e Arraes, os exilados mais nomeados pelos livros didáticos, ganham a companhia de Paulo Freire e de Betinho, o "irmão do Henfil", lembrado na canção O bêbado e o equilibrista, 
imortalizada na voz de Elis Regina, que representa para muitos o hino da anistia.

\section{Considerações finais}

A análise empreendida permitiu ver que a contribuição dada pelos livros didáticos selecionados para entender o tema da anistia é, ainda, muito sucinta. Como se tentou demonstrar, trata-se de uma questão bastante complexa, no seio da qual se cruzam expectativas de diferentes protagonistas, tanto daqueles que queriam dar fim à ditadura e à sua herança, quanto daqueles que queriam uma transição sem ruptura para um regime civil. $\mathrm{E}$, certamente, um desafio mostrar esta complexidade em poucos parágrafos ou, às vezes, em poucas frases. A consulta à bibliografia especializada - que vem crescendo nos últimos anos - contribuiria para ampliar o campo de discussão e para aprofundar questões que são apenas apontadas pelos livros didáticos.

A demanda pela anistia permitiu aproximar grupos de oposição que tiveram experiências diferentes ao longo da ditadura: essa medida foi almejada tanto por aquela geração mais velha, ligada ao nacionalismo de esquerda e que foi excluída da participação política, já em 1964, com o golpe, quanto pela geração mais jovem - aquela de 1968 - que acalentou a esperança de derrubar o regime pelas armas. Da mesma forma, a luta pela anistia foi um laboratório de fazer política para uma geração que cresceu sob a ditadura e que, avaliando as experiências anteriores da oposição, considerou que o caminho a ser seguido, nos anos finais da década de 1970, era a luta pelas liberdades democráticas, pela ocupação do espaço público, pela conscientização do povo.

Consideramos que o tema pode ser usado para traçar relações entre situações do presente e situações do passado. Ao tomar um tema que ocupa hoje as páginas dos jornais - menos do que seria necessário, todavia - pode-se voltar ao passado e enfocar duas diferentes conjunturas: a da segunda metade dos 
anos 1970, quando se deu a luta pela anistia e a aprovação da lei; e aquela que inicia em 1964, quando diferentes categorias de brasileiro(a)s começaram a perder seus direitos políticos, seu trabalho, seu lar, e em muitos casos, sua vida. Pode-se, assim, partir do presente e chegar ao passado, num esforço de apreensão do que significa viver destituído de direitos e ao mesmo tempo, do que significa reconquistar tais direitos através da organização coletiva, do trabalho paciente de busca de adeptos, de pressão frente aos detentores do poder. Esta parece ser uma boa oportunidade para refletir com o(a)s aluno(a)s sobre os direitos que hoje usufruímos e que estavam vetados para aquelas pessoas que viveram durante a ditadura.

Dentro desta lógica propomos a realização de duas atividades para trabalhar o tema em sala de aula. A primeira delas é colocar o(a)s alunas em contato com o material iconográfico e impresso produzido pelos movimento pela anistia. ${ }^{6}$ A partir de fotos, charges, panfletos e jornais é possível captar o que as entidades esperavam conquistar com uma Lei de Anistia. Estas demandas, por sua vez, podem ser comparadas com o texto da referida lei, apresentado como anexo a este artigo. $\mathrm{O}$ conteúdo do material de propaganda das entidades e da lei, por sua vez, podem ser contraposto aos dos votos dados pelos ministros do STF à ADPF 153, acima mencionado. ${ }^{7}$ A questão a ser perseguida nestes múltiplos cruzamentos de fontes seria: até que ponto, a lei de 1979 representou a anistia ampla, geral e irrestrita? A aprovação da lei foi fruto de um consenso nacional? Qual era a composição do Congresso Nacional em agosto de 1979 e quais eram as possibilidades da oposição ver aprovado um projeto de sua autoria?

A segunda sugestão é explorar duas canções relacionadas à campanha: Novo tempo, de Ivans Lins, e O bêbado e o equilibrista, de

6 Parte deste material está disponível no site da Fundação Perseu Abramo http://www. fpabramo.org.br/o-que-fazemos/memoria-e-historia/exposicoes-virtuais/de-amnistiaanistia.

7 O site onde se encontram os vídeos dos votos está mencionado acima. 
João Bosco e Aldyr Blanc (Anexo II). A partir de um panorama inicial sobre o contexto de luta contra a ditadura na segunda metade dos anos 1970 e de algum conhecimento sobre a repressão durante a ditadura, explorar o conteúdo das canções. A que "novo tempo" e a que "perigos" Ivan Lins se refere? O que podem significar as palavras "vingança" e "engano"? O que significa dizer "estamos em cena, estamos nas ruas"? Em O bêbado e o equilibrista, por sua vez, sugerimos contextualizar expressóes como "choram Marias e Clarices", lembrando de Clarice Herzog, cujo marido foi assassinado em 1975; e "não há de ser inutilmente/ A esperança ...”; destacar a expectativa com a volta dos exilados em versos como "... meu Brasil, que sonha/ com a volta do irmão do Henfil,/ com tanta gente que partiu/ num rabo de foguete...”; explorar imagens como "corda bamba" e "esperança equilibrista". Recomendamos ainda investir na familiarização do(a)s aluno(a) s com estas canções: para além de explorar suas entrelinhas, seria uma experiência muito rica possibilitar que a turma - ao acompanhar e cantar as canções em grupo - possa sentir aquilo que sentiam os que as entoavam há trinta anos atrás.

\section{Referências}

\section{Livros didáticos}

BRAICK, Patrícia do Carmo R.; MOTA, Myriam Becho. História das cavernas ao terceiro milênio. v. 3. São Paulo: Editora Moderna, 2005.

CAMPOS, Flávio de; MIRANDA, Renan Garcia. A Escrita da História. São Paulo: Editora Escala: 2005.

COTRIM, Gilberto Vieira. História Global: Brasil e geral. São Paulo: Editora Saraiva: 2005.

FIGUEIRA, Divalte Garcia. História. São Paulo: Ática. 2005.

LIMA, Lizânias de Souza; CARVALHO, Yone de; PEDRO, Antonio. História do Mundo Ocidental. São Paulo: Editora FTD, 2005. 
MORAES, José Geraldo Vinci de. História Geral e Brasil. São Paulo: Editora Atual, 2005.

OJEDA, Eduardo A. B.; PETTA, Nicolina L.; DELFINI, Luciano Emidio. História: uma abordagem integrada. Editora Moderna: São Paulo, 2005.

REZENDE, Antonio Paulo; DIDIER, Maria Thereza. Rumos da História: história geral do Brasil. São Paulo: Atual Editora, 2005.

SCHMIDT, Mario. Nova História Crítica. São Paulo: Editora Nova Geração, 2005.

SERIACOPI, Gislane Campos Azevedo; SERIACOPI, Reinaldo. História. São Paulo: Editora Ática: 2005.

\section{Bibliografia}

ABREU, Alzira Alves (Coord.). Dicionário Histórico Biográfico Brasileiro pós 1930. Ed. atualizada e revisada. v. 2. Rio de Janeiro: Fundação Getúlio Vargas, 2001 (Verbete Comitê Brasileiro pela Anistia).

ARAÚJO, Maria Paula do Nascimento. Lutas democráticas contra a ditadura. REIS FILHO, Daniel Aarão; FERREIRA, Jorge. As esquerdas no Brasil. v. 3. Rio de Janeiro: Civilização Brasileira, 2007.

BICUDO, Hélio. 2009. Anistia e crimes contra a humanidade que não prescrevem. Com Ciência, Revista Eletrônica de Jornalismo Cientifico, n. 106. Disponível em http://www.comciencia.br/comciencia/index. php? section $=8 \&$ edicao $=43 \&$ rid $=525$. Acesso em 10 jul. 2010 .

BORTOT, Ivanir; GUIMARAENS, Rafael. Abaixo a repressão! Movimento estudantil e as liberdades democráticas. Porto Alegre: Libretos, 2008.

CARLOS, Juliana de Oliveira. A Anistia e a Luta pelos Direitos Humanos no Brasil. In: CADERNOS AEL: Anistia e Direitos Humanos. Campinas: Unicamp/IFCH/AEL, v. 13, n. 24/25, 2008.

COIMBRA, Cecília Maria Bouças. Reparação e Memória. In: CADERNOS AEL: Anistia e Direitos Humanos. Campinas: Unicamp/IFCH/AEL, v. 13, n. 24/25, 2008.

GRECO, Heloísa. Dimensões fundacionais da luta pela anistia. Belo Horizonte: UFMG. (Tese de Doutorado em História), 2003. 
KUCINSKI, Bernardo. Abertura, a história de uma crise. São Paulo: Editora Brasil Debates, 1982.

LEMOS, Renato. Anistia e crise política no Brasil pós-64. Topoi, Rio de Janeiro, dez. 2002.

LUNA, Cristina Monteiro Andrada. A Associação Brasileira de Imprensa durante a ditadura. Dissertação (Mestrado em História Social) - Universidade Federal do Rio de Janeiro, 2007.

MARTINS, Roberto Ribeiro. Liberdade para os brasileiros: Anistia ontem e hoje. Rio de Janeiro: Ed. Civilização Brasileira, 1978.

MEZZAROBBA, Glenda. O preço do esquecimento: as reparações pagas às vítimas do regime militar. São Paulo: USP. (Tese de Doutorado em Ciência Política), 2007.

MOREIRA ALVES, Maria Helena. Estado e oposição no Brasil (19641984). Bauru: Edusc, 2005.

REIS FILHO, Daniel Aarão. Ditadura militar, esquerdas e sociedade. Rio de Janeiro: Jorge Zahar Editor, 2000.

RODEGHERO, Carla Simone; DIENSTMANN, G.; TRINDADE, T. Anistia ampla, geral e irrestrita: história de uma luta inconclusa. Porto Alegre, 2010 (No prelo).

RODEGHERO, Carla Simone. A anistia entre a memória e o esquecimento. In: História UNISINOS: Revista do Programa de Pós-Graduação em História da Universidade do Vale do Rio dos Sinos. São Leopoldo. v. 13, n. 2 (maio/ago. 2009).

ROLLEMBERG, Denise. Memória, Opinião e Cultura Política. A Ordem dos Advogados do Brasil sob a Ditadura (1964-1974). In: REIS, Daniel Aarão; ROLLAND, Denis. (Orgs.). Modernidades Alternativas. Rio de Janeiro: Ed. Fundação Getúlio Vargas, 2008.

SELIGMANN-SILVA, Márcio. Anistia e (in)justiça no Brasil: o dever de justiça e a impunidade. In: Literatura e autoritarismo: memórias da repressão, n. 9, jan./jul. 2007. Disponível em http://coralx.ufsm.br/ grpesqla/revista/num09/art_02.php. Acesso em 15 abr. 2009. 
. História, memória, literatura. O testemunho na era das catástrofes (Org.). Campinas: UNICAMP, 2003.

SILVA JR., José Carlos Moreira da. Dever de memória e a construção da história viva: a atuação da Comissão de Anistia do Brasil na concretização do direito à memória e à verdade. In: PADRÓS, Enrique; BARBOSA,Vânia; LOPEZ, Vanessa A; FERNANDES, Amanda S. (Orgs.). Ditadura de Segurança Nacional no Rio Grande do Sul (19641985). Porto Alegre: Corag, v. 4. O fim da ditadura e o processo de redemocratização, p. 47-92, 2009.

SILVA, Haike Kleber da (Org.). A Luta pela Anistia. São Paulo: Imprensa Oficial do Estado de São Paulo/UNESP, 2009.

SKIDMORE, Thomas. Brasil de Castelo a Tancredo. Rio de Janeiro: Paz e Terra, 1987.

\section{Anexos}

\section{Anexo I}

LEI No 6.683, DE 28 DE AGOSTO DE 1979.

Presidência da República - Casa Civil

Subchefia para Assuntos Jurídicos

\section{Concede anistia e dá outras providências}

O PRESIDENTE DA REPÚBLICA: Faço saber que o Congresso Nacional decreta e eu sanciono a seguinte Lei:

Art. $1^{\circ}$ É concedida anistia a todos quantos, no período compreendido entre 02 de setembro de 1961 e 15 de agosto de 1979, cometeram crimes políticos ou conexo com estes, crimes eleitorais, aos que tiveram seus direitos políticos suspensos e aos servidores da Administração Direta e Indireta, de fundações vinculadas ao poder público, aos Servidores dos Poderes Legislativo e Judiciário, aos Militares e aos dirigentes e representantes sindicais, punidos com fundamento em Atos Institucionais e Complementares (vetado). 
$\$ 1^{\mathrm{O}}$ - Consideram-se conexos, para efeito deste artigo, os crimes de qualquer natureza relacionados com crimes políticos ou praticados por motivação política.

$\$ 2^{\circ}$ - Excetuam-se dos benefícios da anistia os que foram condenados pela prática de crimes de terrorismo, assalto, seqüestro e atentado pessoal.

$\$ 3^{\circ}$ - Terá direito à reversão ao Serviço Público a esposa do militar demitido por Ato Institucional, que foi obrigada a pedir exoneração do respectivo cargo, para poder habilitar-se ao montepio militar, obedecidas as exigências do art. $3^{\circ}$.

Art. $2^{\circ}$ Os servidores civis e militares demitidos, postos em disponibilidade, aposentados, transferidos para a reserva ou reformadas, poderão, nos cento e vinte dias seguintes à publicação desta lei, requerer o seu retorno ou reversão ao serviço ativo: (Revogado pela Lei $n^{0} 10.559$, de 2002) I - se servidor civil ou militar, ao respectivo Ministro do Estado; (Revogado pela Lein ${ }^{\circ} 10.559$, de 2002) II - se servidor civis da Câmara dos Deputados, do Senado Federal, de Assembléia Legislativa e da Câmara Municipal, aos respectivos Presidentes; (Revogado pela Lei n ${ }^{0} 10.559$, de 2002) III - se servidor do Poder Judiciário, ao Presidente do respectivo Tribunal; (Revogado pela Lei ${ }^{\circ}$ 10.559, de 2002) IV - se servidor de Estado, do Distrito Federal, de Território ou de Município, ao Governo ou Prefeito. (Revogado pela Lei no 10.559 , de 2002)

Parágrafo único. A decisão, nos requerimentos de ex-integrantes das Políticas Militares ou dos Corpos de Bombeiro, será precedida de parecer de comissões presididas pelos respectivos comandantes. (Revogado pela Lei no 10.559, de 2002).

Art. $3^{\circ} \mathrm{O}$ retorno ou a reversão ao serviço ativo somente deferido para o mesmo cargo ou emprego, posto ou graduação que o servidor, civil ou militar, ocupava na data de seu afastamento, condicionado, necessariamente, à existência de vaga e ao interesse da Administração.

$\$ 1^{\circ}$ - Os requerimentos serão processados e instituídos por comissões especialmente designadas pela autoridade a qual caiba a apreciá-los. 
$\$ 2^{\circ}-\mathrm{O}$ despacho decisório será proferido nos centos e oitenta dias seguintes ao recebimento do pedido.

$\$ 3^{\circ}$ - No caso de deferimento, o servidor civil será incluído em Quadro Suplementar e o Militar de acordo com o que estabelecer o Decreto a que se refere o art. 13 desta Lei.

$\$ 4^{\circ}-\mathrm{O}$ retorno e a reversão ao serviço ativo não serão permitidos se o afastamento tiver sido motivado por improbabilidade do servidor.

$\$ 5^{\circ}-$ Se o destinatário da anistia houver falecido, fica garantido aos seus dependentes o direito às vantagens que the seriam devidas se estivesse vivo na data da entrada em vigor da presente lei. (Revogado pela Lei $\mathrm{n}^{\circ} 10.559$, de 2002).

Art. $4^{\circ}$ Os servidores que, no prazo fixado no art. $2^{\circ}$, não requerem o retorno ou a reversão à atividades ou tiverem seu pedido indeferido, serão considerados aposentados, transferidos para a reserva ou reformados, contando-se o tempo de afastamento do serviço ativo para efeito de cálculo de proventos da inatividade ou da pensão. (Revogado pela Lei n ${ }^{\circ} 10.559$, de 2002).

Art. $5^{\circ}$ Nos casos em que a aplicação do artigo cedida, a título de pensão, pela família do servidor, será garantido a este o pagamento da diferença respectiva como vantagem individual. (Revogado pela Lei $\mathrm{n}^{\mathrm{O}} 10.559$, de 2002).

Art. $6^{\circ} \mathrm{O}$ cônjuge, qualquer parente, ou afim, na linha reta, ou na colateral, ou o Ministro Público, poderá requerer a declaração de ausência de pessoa que, envolvida em atividades políticas, esteja, até a data de vigência desta Lei, desaparecida do seu domicílio, sem que dela haja notícias por mais de 1 (um) ano

$\$ 1^{\circ}$ - Na petição, o requerente, exibindo a prova de sua legitimidade, oferecerá rol de, no mínimo, 3 (três) testemunhas e os documentos relativos ao desaparecimento, se existentes.

$\$ 2^{\circ}-\mathrm{O}$ juiz designará audiência, que, na presença do órgão do Ministério Público, será realizada nos 10 (dez) dias seguintes ao da apresentação do requerente e proferirá, tanto que concluída a instrução, no prazo máximo de 5 (cinco) dias, sentença, da qual, se concessiva do pedido, não caberá recurso. 
$\$ 3^{\circ}-$ Se os documentos apresentados pelo requerente constituirem prova suficiente do desaparecimento, o juiz, ouvido o Ministério Público em 24 (vinte e quatro) horas, proferirá, no prazo de 5 (cinco) dias e independentemente de audiência, sentença, da qual, se concessiva, não caberá recurso.

$\$ 4^{\circ}$ - Depois de averbada no registro civil, a sentença que declarar a ausência gera a presunção de morte do desaparecido, para os fins de dissolução do casamento e de abertura de sucessão definitiva.

Art. $7^{\circ}$ A conhecida anistia aos empregados das empresas privadas que, por motivo de participação em grave ou em quaisquer movimentos reivindicatórios ou de reclamação de direitos regidos pela legislação social, haja sido despedidos do trabalho, ou destituídos de cargos administrativos ou de representação sindical.

Art. $8^{\circ}$ Os anistiados, em relação as infrações e penalidades decorrentes do não cumprimento das obrigações do serviço militar, os que à época do recrutamento, se encontravam, por motivos políticos, exilados ou impossibilitados de se apresentarem.

Parágrafo único. O disposto nesse artigo aplica-se aos dependentes do anistiado.

Art. $9^{\circ}$ Terão os benefícios da anistia os dirigentes e representantes sindicais punidos pelos Atos a que se refere o art. $1^{\circ}$, ou que tenham sofrido punições disciplinares incorrido em faltas ao serviço naquele período, desde que não excedentes de 30 (trinta) dias, bem como os estudantes.

Art. $10^{\circ}$ Os servidores civis e militares reaproveitados, nos termos do art. $2^{\circ}$, será contado o tempo de afastamento do serviço ativo, respeitado o disposto no art. 11 .

Art. $11^{\circ}$ Esta Lei, além dos direitos nela expressos, não gera quaisquer outros, inclusive aqueles relativos a vencimentos, saldos, salários, proventos, restituições, atrasados, indenizações, promoções ou ressarcimentos.

Art. $12^{\circ}$ Os anistiados que se inscreveram em partido político legalmente constituído poderão voltar e ser votados nas convençỗes partidárias a se realizarem no prazo de l (um) ano a partir da vigência desta Lei. 
Art. $13^{\circ}$ O Poder Executivo, dentro de 30 (trinta) dias, baixará decreto regulamentando esta Lei.

Art. $14^{\circ}$ Esta Lei entrará em vigor na data de sua publicação.

Art. $15^{\circ}$ Revogam-se as disposições em contrário.

Brasília, 28 de agosto de 1979; 158 da Independência e $91^{\circ}$ da República.

\section{Anexo II}

\section{O Menestrel das Alagoas}

Interpretação: Milton Nascimento

Composição: Milton Nascimento e Fernando Brant

Quem é esse viajante

Quem é esse menestrel

Que espalha esperança

E transforma sal em mel?

Quem é esse que penetra

No fundo do pantanal

Como quem vai manhãzinha

Buscar fruta no quintal?

De quem essa ira santa

Essa saúde civil

Que tocando a ferida

Redescobre o Brasil?

\section{Novo Tempo}

Interpretação: Ivan Lins

Composição: Ivan Lins / Vitor Martins

No novo tempo, apesar dos castigos

Estamos crescidos, estamos atentos, estamos mais vivos

Pra nos socorrer, pra nos socorrer, pra nos socorrer

No novo tempo, apesar dos perigos 
Da força mais bruta, da noite que assusta, estamos na luta

Pra sobreviver, pra sobreviver, pra sobreviver

Pra que nossa esperança seja mais que a vingança

Seja sempre um caminho que se deixa de herança

No novo tempo, apesar dos castigos

De toda fadiga, de toda injustiça, estamos na briga

Pra nos socorrer, pra nos socorrer, pra nos socorrer

No novo tempo, apesar dos perigos

De todos os pecados, de todos enganos, estamos marcados

Pra sobreviver, pra sobreviver, pra sobreviver

No novo tempo, apesar dos castigos

Estamos em cena, estamos nas ruas, quebrando as algemas

Pra nos socorrer, pra nos socorrer, pra nos socorrer

No novo tempo, apesar dos perigos

A gente se encontra cantando na praça, fazendo pirraça

\section{O bêbado e o equilibrista}

Intrepretação: Elis Regina

Composição: João Bosco e Aldyr Blanc

Caía a tarde feito um viaduto

E um bêbado trajando luto

Me lembrou Carlitos...

A lua

Tal qual a dona do bordel

Pedia a cada estrela fria

Um brilho de aluguel

E nuvens!

Lá no mata-borrão do céu

Chupavam manchas torturadas

Que sufoco!

Louco!

O bêbado com chapéu-coco

Fazia irreverências mil

Prá noite do Brasil. 
Meu Brasil!...

Que sonha com a volta

Do irmão do Henfil.

Com tanta gente que partiu

Num rabo de foguete

Chora!

A nossa Pátria

Mãe gentil

Choram Marias

E Clarisses

No solo do Brasil...

Mas sei, que uma dor

Assim pungente

Não há de ser inutilmente

A esperança...

Dança na corda bamba

De sombrinha

E em cada passo

Dessa linha

Pode se machucar...

Azar!

A esperança equilibrista

Sabe que o show

De todo artista

Tem que continuar... 
